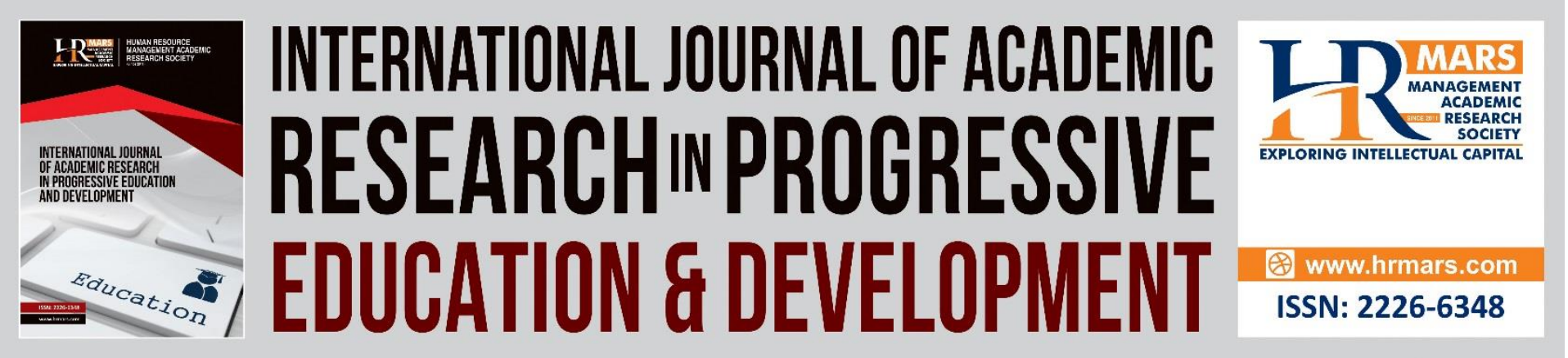

\title{
Questionnaire Reliability: Influence of Environment and Culture on Student Competence
}

Norhazwah Estiar, Abdul Razaq Ahmad, Muhammad Hussin, Hainnuraqma Rahim

To Link this Article: http://dx.doi.org/10.6007/IJARPED/v11-i1/11693

DOI:10.6007/IJARPED/v11-i1/11693

Received: 09 November 2021, Revised: 10 December 2021, Accepted: 30 December 2021

Published Online: 10 January 2022

In-Text Citation: (Estiar et al., 2022)

To Cite this Article: Estiar, N., Ahmad, A. R., Hussin, M., \& Rahim, H. (2022). Questionnaire Reliability: Influence of Environment and Culture on Student Competence. International Journal of Academic Research in Progressive Education and Development, 11(1), 84-96.

Copyright: (C) 2022 The Author(s)

Published by Human Resource Management Academic Research Society (www.hrmars.com)

This article is published under the Creative Commons Attribution (CC BY 4.0) license. Anyone may reproduce, distribute, translate and create derivative works of this article (for both commercial and non-commercial purposes), subject to full attribution to the original publication and authors. The full terms of this license may be seen

at: http://creativecommons.org/licences/by/4.0/legalcode

Vol. 11(1) 2022, Pg. 84 - 96

http://hrmars.com/index.php/pages/detail/IJARPED

JOURNAL HOMEPAGE

Full Terms \& Conditions of access and use can be found at http://hrmars.com/index.php/pages/detail/publication-ethics 


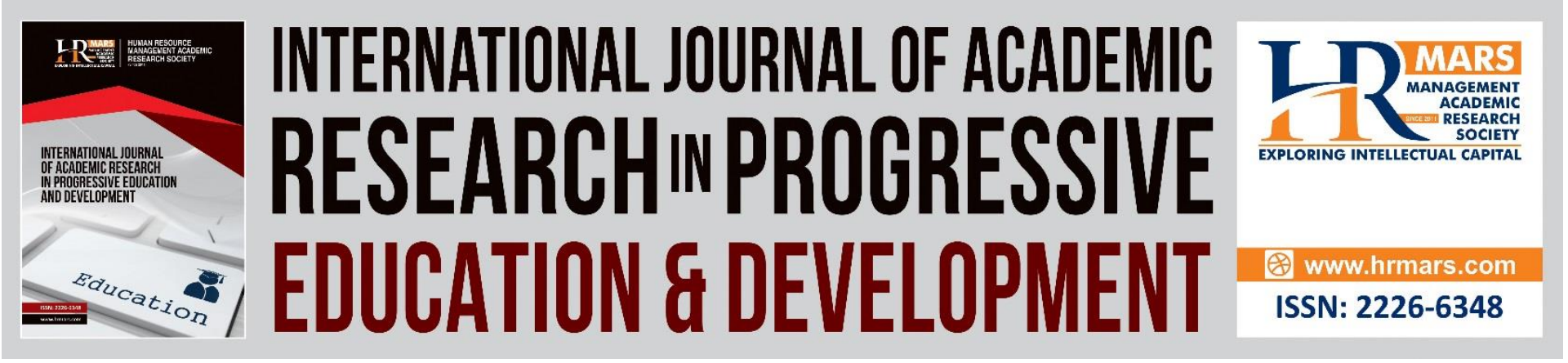

\title{
Questionnaire Reliability: Influence of Environment and Culture on Student Competence
}

\author{
Norhazwah Estiar, Abdul Razaq Ahmad, Muhammad Hussin \\ Fakulty of Education, Universiti Kebangsaan Malaysia (UKM), 43600, Bangi, Selangor \\ Email: norhazwahestiar@gmail.com, razaq@ukm.edu.my,muhsin@ukm.edu.my
}

Hainnuraqma Rahim

Faculty of Business and Management, Center for Islamic Philanthropy and Social Finance (CIPSF), Universiti Teknologi MARA (UiTM), Cawangan Melaka, KM 26, Jalan Lendu, 78000

Alor Gajah Melaka

Email: hainnuraqma@uitm.edu.my

\begin{abstract}
This pilot study was conducted to examine the reliability of questionnaire used in the survey on the influence of environment and culture to UKM student competence. The questionnaire comprised of 118 items which are categorised into 6 parts. Part A pertains to the demographic background with 9 items, and Part B on the influence of student environment with 7 items. Next, Part C pertains to student culture (interpersonal) with 7 items, and Part D on student culture (socialization)) with 7 items. Then, Part E pertains to competency (communication skills) with 15 items. Finally, Part F pertains to competency (critical thinking and problem solving skills) with 30 items. A total of 30 UKM students were involved in this pilot study. Questionnaire was analysed using the SPSS version 23 . The overall reliability result was 0.923 , which was the best score. Meanwhile, for the breakdown of the questionnaire section $B, C$, $D, E$ and $F$, the Cronbach's Apha value for each section is in the range of 0.565 to 0.820 . The Cronbach's alpha value presented a good interpretation pertaining to the reliability of the questionnaire developed.
\end{abstract}

Keyword: Questionnaire, Environmental Influence, Competence, UKM Students, SPSS

\section{Introduction}

In terms of academic elements, environmental aspects focus on elements such as influences from family, internet access, peers, lecturers and community. Meanwhile, aspects of student culture involve interpersonal and student socialization. These are the important variables in determining influences of environment and culture on student competence. In terms of graduate competencies, the focus is on communication skills and critical thinking competencies. In addition, the students' demographic backgrounds do influence the environment, culture and also competencies.

Higher learning institutions, as well as skill training centres produce students who aimed to achieve the required academic level of qualification for their future career aspirations. These academic and skill institutions equip graduates with knowledge, training and abilities so as to 
fill in job opportunities and prospects for workplace environment in the appropriate fields and career interests. Nevertheless, statistics of local labour markets showed that the output of local higher education and training institutions, especially public universities, was insufficient to fulfil job vacancies even though the output of graduates are many. Unfortunately, these graduates could not really fulfil the criteria which the employers sought for (Kementerian Pelajaran Tinggi, 2020). Looking at these constraints, the researchers found the need for a study to be done on the competencies of graduates. Thus, this study focuses on identifying the influence of environment and culture on student competencies.

For the purpose of producing students who can compete globally, the Malaysia Education Development Plan 2013-2025 has emphasized six student aspirations, namely knowledge, leadership skills, bilingual skills, ethics and spirituality, national identity and thinking skills. Current students need to master these elements in order for them to compete professionally in their future career choice and in the workplace environment. Othman \& Hassan (2019) agreed that to survive and succeed in professional organizations, graduates should acquire job competencies and skills in order to face high competitions in the job market.

In fact, it could be observed that current socio-economic developments require higher learning institutions to produce suitable graduates in accordance to the current demands of economic technology developments. Moreover, students need to be nurtured and trained with various knowledge, skills, and trainings to fulfil the current job requirements. Hence, this study has looked into the various aspects of competence of students in Universiti Kebangsaan Malaysia which are needed in order to meet the current requirements of employers, job market and society.

This emerging issue was also reported by Subra et al (2019) who were concerned with the current phenomenon of dropouts from learning institutions which could pose as a waste to the efforts made in the educational progress in Malaysia. This issue is unfortunate to the nation as the government has made various concerted efforts to bridge the education gap and enhance education opportunities for youths in Malaysia. Several researches showed that the influence of the environment, interpersonal and socialization aspects have an impending role towards student competency. It was found to be inconsistent in influencing students' competencies, especially in terms of communication and creative thinking skills.

Therefore, the efforts to measure the influence of environment and culture on the competencies of university students require a solid, robust and accurate questionnaire in order to effectively measure the need to identify the relationships between environment and culture which are closely related to competencies. This effort is important as the results gathered could path the way towards understanding the aspects which are essentially significant in producing quality graduates in UKM.

\section{Statement of Problem}

The challenges of Institutions of Higher Learning (HEIs) today are closely related to efforts towards providing the human capital that the industry really needs (Makhbul et. al., 2015). This issue is also supported by Subra et. al (2019) who stated that phenomenon of dropouts and students with low academic achievements were a waste of educational progress in Malaysia. This current issue is unfortunate as the government has made various concerted efforts to bridge education gap and made serious efforts to provide Malaysian youths with education opportunities. Mohammed dan Langkan (2018) stated that this situation occurred due to the dumping and piling of graduates into the labour market which could affect the national economy and induce the number of unemployment rates. Besides that, the 
competence level among university students are influenced by their environment such as in terms of the challenges of the relationship with lecturers, as well as academic demands. Moreover, Abdul Hamid (2006) found that weaknesses in aspects of problem solving, and decision making were among the main causes of the problem. A more troubling issue was that graduates were said to be unable to provide critical views and ideas. Mustapha (1999) stated that employers involved in the Malaysian manufacturing sectors believed that Malaysian technical graduates did possess more technical skills. Nonetheless, the employers were dissatisfied with their critical thinking and problem solving skills, which were part of the job skills which these technical graduates lack which were important in order to handle the technical problems in firms and manufacturing industries. Unfortunately, these technical graduates were found to still be at the level of the previous old environment. As technology advanced quickly, these graduates are not at par with current technology requirements. Students were still not ready to step into new environments and experiences at the transition stage from academic to industrial environments. Among the main challenge faced by students was financial problem (Noor, 1996). Besides that, one of the challenges for university students to achieve competence was in terms of relationships with lecturers as well as their academic demands.

Hence, as current youths are to become future human capital resources for the country, it is hoped that researchers pay attention towards the issues mentioned above so as to enhance the marketability of graduates produced. This means that further studies should be conducted in order to understand the aspects of environmental and cultural impact towards the abilities and competencies of UKM graduates.

\section{Literature Review}

Durlak, Weissberg \& Pachan (2010) reported that the environment of having peers was important for individual development of students. Moreover, in the university environment, peers play a key role in influencing students' academic development (Leng, 2006). Later on, Salleh et al. (2011) showed that close relationships with peers tend to create a positive impact for academic achievement. In fact, peers are a group of people who are very close to students in school. This means that peers have a strong influence on other students in terms of whether students perform good or bad deeds.

In addition, access to internet does influence youths and students. Past research done on social network showed that Malaysian youths tend to engage in certain social networks, such as Facebook, because they have a strong sense of belonging (Shadan, 2010). Moreover, the diversity of website resources on the internet helps students to obtain a variety of learning materials such as interactive quizzes, or even online tutorial classes which could help students to understand their subjects better. In social terms, most students with $63.4 \%$ indicated that they used the internet to get more friends and contacts. Matore (2010) presented that the estimated number of the most dominant friends in a student's Facebook is between 201 and 300 friends where it accounted for $36 \%$.

Next, a lecturer also plays a very important role in influencing students to achieve success goals (Salleh et al., 2009). Volery and Deborah (2000) added that a lecturer's support such as feedback, communication and timely assistance are essential elements in the learning process. Current study by Razila (2019) stated that quality teachers consist of individuals who can master and realize all forms of skills and knowledge. This is because effective teaching and learning processes provide quality teaching, which will ultimately affect students' test scores. 
In addition, previous studies by Ali \& Noordin (2010); Mohamed et al (2007) stated the main problem of graduates not getting relevant employments was due to communication problems. Ali \& Noordin (2010) contended that the main factor of communication problems was due to the lack of students 'proficiency to communicate well in English. Slocum et. al (2008) also emphasized that the most important self-management ability was from a communication perspective. Communication competence could strengthen the foundation of management success. Communication is also an important element to ensure effective management. However, sometimes managers disregard the importance of communication competence. Slocum et. al (2008) further asserted that if managers master communication skills, they are able to develop their influence and effectiveness.

Although individuals need to possess a certain level of academic qualification sometimes so as to enter a low job market, academic recognition remains an important aspect in determining an individual's marketability. A study by Chew (2017) also added that current students who are weak in higher thinking order skills (HOTS) need to be aware that HOTS is a required skill which could be found in all education levels (Chew, 2017). Stated that graduates were unable to demonstrate their knowledge and skills in the process of problem analysis, find a variety of methods, synthesize, make suggestions in solving, create solutions, and learn from workplace experiences. As a result, the majority of student graduates were unable to meet the employee characteristics required by the private and public sectors. Moreover, the importance of this study responds to national education policy in accordance to national education planned missions and objectives. In fact, students are required to go through a long-term education plans from primary to secondary school levels. Therefore, by producing high quality workforces, we can also achieve high quality and skilled human capital for the workplace environments.

\section{Study Significance}

This research not only provides added value in the field of sociology education, but also adds to the body of knowledge to the field of leadership and adult education. Therefore, the aim of the study was to identify the abilities of students which were influenced by other aspects such as environment and culture. Therefore, the researchers hoped that the results of this study could help improve the abilities of students especially UKM graduates.

In addition, the findings from this study could also provide some additional knowledge to public and private universities and the Ministry of Higher Education Malaysia so as to emphasize the importance of improving the influential environment and appropriate culture towards nurturing graduate competency skills. This understanding is important as graduates and industries are aspects that could drive Malaysian economy and industry to compete in the global economy in the Fourth industrial revolution era.

Essentially, the objective of this pilot study is to evaluate the reliability of the questionnaire constructed and outline the references referred to in the sub-construction of item variables identified for the study questionnaire. Stated that the performance of a university is usually measured by the interpersonal skills of its graduates. It is important that to produce competent graduates, interpersonal skills be developed not only at the national level, but also in terms of international level considerations.

\section{Methodology}

This descriptive study aims to obtain the reliability value of the instrument. There are 118 items presented in the questionnaire which are divided into 6 parts. Part A pertains to 
demographic background with 9 items. Next, Part B is the influence of student environment of 7 items, and Part $C$ is on student culture (interpersonal) of 7 items. Whereas, Part D pertains to student culture (socialization skills) with 7 items and part E deals on competency (communication skills) with 15 items. Finally, Part F pertains to competency (critical thinking and problem solving skills) with 30 items.

Furthermore, the research tool used was questionnaire to achieve the objective of the study in investigating the influence of environment and culture to student competence. A total of 30 students who were categorized as homogeneous were involved in this pilot study. Selected student respondents have similar characteristics with the actual respondents in the actual study. For the purpose of this pilot study, this questionnaire was referred to as the Questionnaire on the influence of environment and culture on student competence. The number of item sub-construct and the references referred to in the development and construction of this questionnaire are listed in Table 1 below:

Table 1: Number of Sub-Construct/Items and Reference Sources

NO. SUB-CONSTRUCT REFERENCES

1 DEMOGRAPHY

(9 ITEMS)

2 INFLUENCES FROM FAMILY (7 ITEMS)

3 PEER INFLUENCE (7 ITEMS)
1. Sidek, Rosni Zamuddin Shah \& Abu Bakar, Norfazila (2010) Faktor-Faktor Yang Mempengaruhi Minat Pelajar Tahun Akhir Terhadap Bidang Keusahawanan Di UTM. Journal of Science \& Mathematics Education. pp. 1-10.

1. Mohamad Isa Bin Azis .2011. Pertautan Ibu Bapa Dan Rakan Sebaya Dalam Kalangan Pelajar Universiti Serta Hubungannya Dengan yakin Diri Dan Eksplorasi Diri. Tesis Dr. Fal, Fakulti Pendidikan, Universiti Kebangsaan Malaysia.

2. Sidek, Rosni Zamuddin Shah \& Abu Bakar, Norfazila (2010) Faktor-Faktor Yang Mempengaruhi Minat Pelajar Tahun Akhir Terhadap Bidang Keusahawanan Di UTM. Journal of Science \& Mathematics Education . pp. 1-10.

1. Mohamed Isa Bin Azis. 2011. Pertautan Ibubapa Dan Rakan Sebaya Dalam Kalangan Pelajar Universiti serta Hubungan Dengan Yakin Diri dan Eksplorasi Diri. Tesis Dr. Fal, Fakulti Pendidikan, Universiti Kebangsaan Malaysia.

2. Sidek, Rosni Zamuddin Shah \& Abu Bakar, Norfazila (2010) Faktor-Faktor 


\section{$4 \quad$ INFLUNCES FROM INTERNET (7 ITEMS)}

\section{INFLUENCES FROM LECTURERS (7 ITEMS)}

\section{INTERPERSONAL (15 ITEMS)}

Yang Mempengaruhi Minat Pelajar Tahun Akhir Terhadap Bidang Keusahawanan Di UTM. Journal of Science \& Mathematics Education. pp. 110.

1. Ting, Kung Shiung (2007) Kajian mengenai penggunaan e-pembelajaran (e-learning) di kalangan pelajar jurusan pendidikan teknik dan vokasional di institusi pengajian tinggi (IPTA) negeri Johor. Master's thesis, Universiti Teknologi Malaysia, Faculty of Education.

2. Nor Arinah Mohamed Zemudin, \& Mohd Azul Mohamad Salleh. 2017. Mudah Guna Dan Kebergunaan Laman Web Universiti Dalam Kalangan Pelajar Antarabangsa. Journal Social Science and Humanities.Vol. 12, No. 1 (2017) 001-012, ISSN: 1823-884x

1. Sidek, Rosni \& Zamuddin Shah. Yang Mempengaruhi Minat Pelajar Tahun Akhir Terhadap Bidang Keusahawanan Di UTM. Journal of Science \& Mathematics Education. pp. 1-10.

2. Salleh, Muhammad Shukri, Amir Razli, Meer Zhar Farouk, Yusoff \& Mohd. Zahari (2006) Faktor-faktor mempengaruhi pencapaian akademik yang rendah di kalangan mahasiswa/i Universiti Teknologi MARA (UiTM) Kelantan bagi semester Disember 2005Mei 2006. In: National Student Development Conference (NASDEC) 2006, 8-9 August 2006, Kuala Lumpur, Malaysia.

1. Sayuti, Rusimah, Abdullah, Mohamad Ainuddin Iskandar Lee, Ishak \& Salma (2004) Kajian hubungan kaum di kalangan pelajar Sekolah Pembangunan Sosial, Universiti Utara Malaysia. In: Seminar Antarabangsa Nilai dalam Komuniti Pasca Modenisme (SIVIC 2004), 4-6 September 2004, Hotel City Bayview Langkawi.

2. Nurul Salmi \& Mohd Isha. 2014. Tahap Kemahiran Komunikasi Dalam Kalangan 
DEVELOPMENT

Vol. 11, No. 1, 2022, E-ISSN: 2226-6348 @ 2022 HRMARS

7 SOSIALISATION

(15 ITEMS)

8

COMMUNICATION COMPETENCY (30 ITEMS)
Pelajar Sarjana Muda Pendidikan IPTA Di Utara Semenanjung Malaysia. Jurnal Pendidikan Bahasa Melayu. ISSN: 21804842. Vol. 4, Bil. 2 (Nov. 2014): 44-56

1. Norasmah. 2017. Daya Tahan Pelajar Universiti Awam dan Universiti Swasta. Jurnal Pendidikan Malaysia. 42(1) (2017): 77-86

2. Tengku Elmi Azlina, Shazarina, Mohamad Fuad \& Ahmad Shafiq. 2014. Kemahiran Sosial Menurut Perspektif Islam: Aplikasinya Dalam Membentuk Keperibadian Pelajar. Jurnal Pendidikan. Bil 1 (2) 2014

ADAPTATION: Jamaludin, Rosna, Mod Majid, Turiman, Maria \& Norhafezah. 2009. Pembangunan pelajar memperkasakan kokurikulum Institut Pengajian Tinggi. Penerbit Universiti Putra Malaysia: Serdang.

ADAPTATION: Jamaludin, Rosna, Mod Majid, Turiman, Maria \& Norhafezah. 2009. Pembangunan pelajar memperkasakan kokurikulum Institut Pengajian Tinggi. Penerbit Universiti Putra Malaysia: Serdang.

\section{Data Analysis}

The data of this pilot study was analysed using the SPSS Version 23 to obtain the overall Cronbach's Alpha reliability results and the value of each construct. This means that some of the things assessed were interpretations based on the values of reliability. Moreover, the researchers used SPSS Version 23 analysis to test the overall reliability of items and constructs using the overall Cronbach's Alpha values of an instrument.

\section{Findings}

A total of 30 UKM student respondents responded to the survey questionnaire. Data was collected and analysed descriptively; the minimum level used in this analysis was the value of Cronbach's Alpha reliability coefficient 0.70 . This value is in accordance to the recommendation by Creswell (2018). It is important to ensure that the questionnaire constructed has a high consistency in measuring the aspects which should be measured (Sidek \& Jamaluddin, 2005). In fact, the reliability analysis obtained found that the instrument has a good reliability value.

Kamaluddin \& Sulaiman (2018) emphasized that the validity of a questionnaire instrument can be measured based on the relationship or correlation between the total score with each item. In addition, the validity of an instrument is also referred to as the corrected value of the item corrected with the total score (Corrected Item-Total Correlation), which is the Pearson 
correlation coefficient between the score of each item with the total score without the item. Thus, there is a recommendation by a previous study by Tabachnick \& Fidell (2013) which stated that the minimum applicable coefficient value is at 0.3 . Reliability is the internal stability and consistency of the instrument to measure a concept.

Table 2: Cronbach's Alpha Values

\begin{tabular}{ll}
\hline Cronbach's Alpha values & Explanation \\
\hline$<0.6$ & Weak \\
0.60 to $<0.70$ & Moderate \\
0.71 to $<0.80$ & Good \\
0.81 to $<0.90$ & Very good \\
$>0.90$ & Best \\
\hline
\end{tabular}

(Source: Bond \& Fox, 2007)

Table 2 illustrated the level where the validity and reliability is at a high level if the range of alpha values are between 0.6 to 0.9 as it is approaching the value of 1 . On the other hand, if the alpha value is less than 0.6 , this means that the level of reliability is low (Chua, 2014). The justification of the researchers conducting the pilot study is to examine the accuracy of the instrument because according to Babbie (2002), there are three types of results obtained while conducting a pilot study. First, the data is reliable but invalid. Second, the data is valid but unreliable. Third, the data is valid and reliable. Cooper \& Schindler (2013) stated that the higher the value of reliability, the smaller the error found in the study instrument. Nevertheless, according to Sekaran \& Bougie (2016), the validity of a study is not necessarily acceptable if the alpha value is high. Such problems could however be overcome by conducting the Test-Retest Reality analysis if the results of the pilot study were vague or the alpha values obtained were too low (Hair et al., 2007; Berenson et. al, 2009).

Accordingly, the above results showed that the overall Cronbach's Alpha value was high at 0.820 indicating a value above 0.60 . While in terms of constructs, the lowest value for the item construct of influence from internet showed 0.594. Meanwhile, the highest value was for item construct of soft skills (communication skills) which showed 0.820 . This means that the construct of this instrument was appropriate in terms of content to measure the influence of the environment of UKM students on student competence. The table of results of the study findings are as below:

Table 3: Cronbach's Alpha Reliability Value

\begin{tabular}{lcc}
\hline Item construct & No. of items & Reliability value \\
\hline Influences from family & 7 & 0.745 \\
Influences from families & 7 & 0.792 \\
Influences from internet & 7 & 0.594 \\
Influences from lecturers & 7 & 0.647 \\
Student culture (interpersonal) & 15 & 0.565 \\
Student culture (socialization) & 15 & 0.645 \\
Competency (Communication skills) & 30 & 0.820 \\
Competency (Critical thinking and & 30 & 0.796 \\
problem solving skills) & & \\
\hline Overall total & 118 & 0.923 \\
\hline
\end{tabular}


DEVELOPMENT

Vol. 11, No. 1, 2022, E-ISSN: 2226-6348 @ 2022 HRMARS

\section{Discussion and Conclusion}

The results of the pilot study presented that the developed questionnaire for the survey done on the influence of environment and culture on student competence was suitable to the items measuring the influence of family, peer influence, internet influence, student culture (interpersonal, socialization), and also student competencies (communication and critical thinking skills and problem solving skills).

Essentially, based on the questionnaire analysis, the level of environment and the level of culture and the level of competence among UKM students were at a high level. Findings also showed that there were significant differences in culture according to students' gender and family income. Next, there were also significant differences in competencies based on parents or guardians' education level. Results also indicated that there was a significant relationship in the environment and culture based on communication skills. In addition, there was a significant relationship in the environment and culture based on critical thinking and problem solving skills. The family sub-dimension also showed a major influence in this study.

This study is very important as it provided more detailed information on the influence of environment and culture on graduate competence. This could contribute to helping educators and lecturers expand their knowledge and awareness with regards to the appropriate environment that could affect students, especially in the UKM campus environment. In brief, students are influenced by the existing environment and culture and communication skills, as well as critical thinking and problem solving that must be embalmed by every student and prospective graduate, especially in order to face future workplace environment. This is because employers and industries require graduates who are competent and skilful workers so as to create organisations with positive, systematic and high productivity environments.

\section{Contribution of Study}

This research provided empirical results that would give motivation to the students in order to improve the important skill such as communication, critical thinking, problem solving, and creativity. It also can give a guideline to university in determines their students need and help university in enhancing the performance and effectiveness of the students through fulfilling employer need.

Other than that, this study may have some significant contributions to the management of university to create a new guideline to all students and lecturer and more focus to environment and culture of university which can give motivation to them to compete with the challenging market. This research shows the role of university as a responsible institution to provide the overall aspect of the university environment that can give effect to competency student. Therefore, the management of university should play an important role to improve the quality of students regarding to the culture and environment of campus life.

The present study also will provide the mechanism related to how to strengthen the relationship influence of environment and culture on the competencies of university students. Thus, this research would motivate academician to help in formulating appropriate policies and procedures concerning the training about teaching methods and provision of conducive environment in the university. It aso can motivate academician and students to improve the student learning outcome and their classroom teaching practices particularly those who face problems of teaching.

Last but not least, this research also helps policy makers in improving their existing policy at organization. The Ministry of Higher Education (MOHE) of Malaysia can also make the findings 
of this study as a major reference for the improve quality education and produce competent and skilled graduates to fulfil the labour force demand. Therefore, MOHE can apply this study to all public universities as the major reference to improve and sustain the standard of university environment which can attract students to engage in quality of campus life.

\section{Acknowledgment}

We would like to express our sincere gratitude to Professor Dato Dr Abdul Razak bin Ahmad and Professor Datuk Dr Muhammad bin Hussin from Universiti Kebangsaan Malaysia for their suggestions and guidance.

\section{Corresponding Author}

Norhazwah Binti Estiar, Faculty of Education, Universiti Kebangsaan Malaysia, Malaysia.

Email: norhazwahestiar@gmail.com

\section{References}

Abdul Hamid, S. Z. (2006). Tahap penguasaan kemahiran berfikir secara kritis dan kreatif (KBKK) di kalangan pelajar tingkatan lima dalam mata pelajaran kimia tingkatan empat di sekolah menengah di daerah Johor Bahru [Bachelor's Thesis, Universiti Teknologi Malaysia].

Ali, M., \& Noordin, S. (2010). Hubungan antara kemahiran berfikir kritis dengan pencapaian akademik dalam kalangan pelajar Fakulti Pendidikan Universiti Teknologi Malaysia. Jurnal Teknologi, 52(1), 45-55. doi:10.11113/jt. v52.136.

Babbie, E. (2002). The basics of social research (2nd ed.). Belmont, CA: Wadsworth.

Berenson, M. L., Baruch, B. M., Levine, D. M., \& Krehbiel, T. (2009). Basic business statistics (11 $1^{\text {th }}$ ed.). New York: Pearson.

Bond, T. G., \& Fox, C. M. (2007). Applying the Rasch model: Fundamental measurement in the human sciences ( $2^{\text {nd }}$ ed.) Mahwah, New Jersey: Lawrence Erlbaum.

Chew, B. G. (2017). Pengetahuan dan pengaplikasian kemahiran berfikir aras tinggi dalam kalangan guru teknik dan vokasional. [Unpublished Doctoral Thesis]. Universiti Tun Hussein Onn Malaysia].

Chua, Y. P. (2014). Kaedah Penyelidikan ( ${ }^{\text {rd }}$ ed.). Shah Alam: Mc Graw Hill Education.

Cooper, D. R., \& Schindler, P. S. (2013). Business Research Method (12 $2^{\text {th }}$ ed.). New York: McGraw-Hill.

Creswell, J. W., \& Creswell, J. D. (2018). Research design: Qualitative, quantitative, and mixed methods approach ( $5^{\text {th }}$ ed.). SAGE.

Durlak, J. A., Weissberg, R. P., \& Pachan, M. (2010). A meta-analysis of after-school programs that seek to promote personal and social skills in children and adolescents. American journal of community psychology, 45(3-4), 294-309. https://doi.org/10.1007/s10464010-9300-6.

Hair, J. F., Money, A. H., Samouel, P., Page, M., \& Samouel, P. (2007). Research methods for business. West Sussex, England: John Wiley \& Sons.

Kamaluddin, M. R., \& Sulaiman, W. (2018). Teknik Kesahan dan Kebolehpercayaan Alat Ujian Psikologi. Bangi, Kuala Lumpur: Universiti Kebangsaan Malaysia.

Kementerian Pengajian Tinggi Malaysia. (2020). Laporan Kajian Pengesanan Graduan. https://www.moe.gov.my/en/muat-turun/laporan-dan-statistik/pendidikantinggi/laporan-kajian-pengesanan-graduan/2018-11. 
DEVELOPMENT

Vol. 11, No. 1, 2022, E-ISSN: 2226-6348 @ 2022 HRMARS

Leng, Q. M. (2006). Hubungan antara sikap, minat, pengajaran guru dan pengaruh rakan sebaya dengan pencapaian matematik di kalangan pelajar Tingkatan Empat di Daerah Batu Pahat, Johor. [Unpublished Bachelor's Degree Thesis] Universiti Teknologi Malaysia.

Makhbul, Z. M., Yussof, I., \& Awang, A. H. (2015). Antara realiti dan harapan: Kajian empirikal persepsi majikan terhadap prestasi graduan tempatan. Geografia: Malaysian Journal of Society and Space, 11(10), 27-36. ISSN 2180-2491.

Mohamed, A., Isa, M. F. L., \& Shafii, H. (2007). Kemahiran di kalangan graduan sebagai kriteria penting pasaran tenaga kerja: Kajian kes graduan Fakulti Kejuruteraan, UKM. [Paper presentation]. Seminar Pendidikan Kejuruteraan dan Alam Bina 2007, Universiti Kebangsaan Malaysia.

Mohammed, R., \& Langkan, F. J. (2018). Isu kebolehpasaran dan kebolehgajian graduan prau tingkatan enam di bahagian Pantai Barat Selatan Sabah. Journal of Global Business and Social Entrepreneurship, 4(10), 96-105.

http://gbse.com.my/v4no10JANUARY2018/Paper-156-.pdf.

Matore, M. E. (2010). Fenomena yang membawa ketagihan. [Paper presentation]. Regional Conference on Knowledge Integration in ICT (2010), Kolej Universiti Islam Antarabangsa.

Noor, M. Y. (1996). Kaunseling dalam pengajian tinggi. In Aminah Hashim \& Arthur P.L. (Eds), Bimbingan dan Kaunseling dalam Pendidikan (pp. 506-526). Kuala Lumpur: Federal.

Mustapha, R. (1999). The role of vocational and technical education in the industrialization of Malaysia as perceived by educators and employers. [Doctoral Thesis, University Purdue].

Othman, N. M., \& Hassan, A. (2019). Elemen Kesediaan Kerjaya ke Arah Kebolehpasaran Graduan Kolej Vokasional Bidang Hospitaliti di Malaysia Berdasarkan Keperluan Pensyarah. Journal of Management and Operation Research 1(20), 1-9. https://ecdcpublishing.com/wp-content/uploads/2018/10/JoMOR-2019-VOL-1-NO20.pdf.

Razila, H. (2020). Pengaruh peran, kinerja dan kompetensi auditor internal terhadap efektivitas sistem pengendalian internal (Studi empiris satuan kerja badan layanan umum UIN Suska Riau). [Master's thesis, Fakultas Ekonomi dan Ilmu Sosial, Universitas Islam Negeri Sultan Syarif Kasim Riau].

Salleh, M. J., Mohamed, A., Mohamed, H., \& Ade, A., S. (2011). Peer influences in academic achievements and behaviours among students of MARA Junior Science College, Malaysia. [Paper presentation]. Seminar Kebangsaan Kaunseling Silang Budaya. Kaunseling Merentas Kepelbagaian Budaya Membentuk 1-Malaysia, Universiti Malaysia Sarawak.

Sekaran, U., \& Bougie, R. (2016). Research methods for business: A skill building approach ( $7^{\text {th }}$ ed.). West Sussex: Wiley \& Sons.

Shadan, A. (2010). 18 Sms Sehari. Kosmo. http://www.kosmo.com.my/ kosmo/content.asp?y=2008\&dt=0911\&pub=Kosmo\&sec=Infiniti\&pg=in_01.html.

Slocum, J. W., Jackson, S. E., \& Hellriegel, D. (2008). Competency-Based Management. Mason, $\mathrm{OH}$ : Thompson South-Western.

Subra, T. H., Lee Abdullah, M. A., \& Devi, K. (2019). Pengaruh sosioekonomi keluarga terhadap keciciran pelajar-pelajar India: Kajian kes di daerah Kuala Muda Kedah. International Journal, 2(9), 77-91. DOI: 10.35631/IJMTSS.29007. 
INTERNATIONAL JOURNAL OF ACADEMIC RESEARCH IN PROGRESSIVE EDUCATION AND

DEVELOPMENT

Vol. 11, No. 1, 2022, E-ISSN: 2226-6348 @ 2022 HRMARS

Tabachnick, B. G., \& Fidell, L. S. (2013). Using multivariate statistics (6 ${ }^{\text {th }}$ ed.). New Jersey: Pearson.

Volery, T., \& Lord, D. (2000). Critical success factors in online education. The International Journal of Education Management, 14(5), 216-

223.https:doi.org/10.1108/0951340010344731. 